\title{
Geographical Indications: An Assessment of EU Treaty Demands ${ }^{1}$
}

\author{
Hazel Moir
}

\section{Introduction}

Modern 'trade' treaties cover a wide range of market interventions and regulations. The five post-2006 Global Europe treaties are no exception. ${ }^{2}$ As with US trade agreements they all include intellectual property (IP) regulations. IP regulations sit uneasily in a trade agreement as their purpose is to limit competition, not to increase it. The major benefits from trade agreements are through their impact on increasing competition.

The European Union (EU) and the United States of America (USA) failed to achieve their full IP agenda in the Uruguay Round. Undaunted, both have been pursuing their unmet IP goals through a series of bilateral and regional agreements, often with quite small trading partners. This chapter focuses on the issue that most distinguishes EU IP demands: geographical indications (GIs) for foodstuffs. GI demands are often

1 The discussion in the earlier sections of this chapter draws on two more detailed papers on geographical indications (Moir 2015a, 2015b).

2 The sixth—with Vietnam—was agreed on 2 December 2015. 
referred to as a deal-breaker. All five post-Global Europe agreements include GI provisions, and it is unlikely that any EU agreement could proceed without at least some coverage of this area.

This chapter commences by reviewing the provisions on GIs in the Agreement on Trade-Related Aspects of Intellectual Property Rights (TRIPS), and then turns to how GIs have been implemented in the EU in the period since the Uruguay Round negotiations began. The discussion of the EU's experience allows a focus on the rationales that have been put forward for the GI intervention in the market. These rationales are critically assessed. This provides essential background to the final section of this chapter-evaluating the EU's GI demands in bilateral trade agreements, and Australia's potential responses.

\section{TRIPS and GIs}

GIs are about what things can be called. They are about labelling, packaging and marketing. Nothing in GI rules prevents any producer anywhere from using the techniques specified as being associated with the GI name. But they may not use the name to communicate the production techniques they have used.

GIs are collective marks signalling the region from which a product comes. The product characteristics must derive from the land and climate (the 'terroir'). GIs originated in Europe and are currently available only for agricultural products.

TRIPS makes only modest provisions for GIs and provides substantial protection for trademark owners (Articles 22 to 24). Both from the perspective of the EU and major New World agricultural exporters, such as Australia, the TRIPS outcome was a compromise (Geuze 2009).

In TRIPS, the EU gained 'strong-form' GIs for wines and spirits. With strong-form GIs, no producer from outside the designated region may use the protected name, even with qualifiers. While an identical product may be produced, any reference to a protected name-for example, 'champagne-style wine, product of Australia'-is not allowed. 
For all other products, TRIPS mandates only 'weak-form' GIs. Countries are free to determine the form GIs take. New World countries have generally used a trademark system of collective and/or certification marks. This allows producers from outside the named region to use labels such as 'Parmesan-style cheese, made in New Zealand'.

TRIPS has substantial 'grandfathering' safeguards ${ }^{3}$ —even strong-form GIs do not have to be adopted. TRIPS safeguards generic names and existing trademarks, protecting the community and trademark owners from expropriation. Article 24 provides that those with existing trademarks, or having used a name continuously for at least 10 years, may continue to use those names, with no provisos, even if they are for wines or spirits.

Nonetheless, some countries have signed EU wine and spirit agreements, adopting strong-form GI privileges in exchange for improved access to EU wine and spirit markets. Australia was one of the first countries to sign a wine agreement with the EU, in 2004. The EU also has wine agreements with other New World countries. ${ }^{4}$ The improved market access provisions of these agreements effectively compensated wine producers for their relabelling and associated marketing costs. Because GI issues on wines have been largely settled through these agreements, this chapter concentrates on GIs for foodstuffs.

\section{EU Gl policy for foodstuffs}

The EU framework for the protection of GIs for foodstuffs was established in $1992,{ }^{5}$ building on earlier systems in place in a few member countries. The system was revised in $2006^{6}$ following a dispute brought against the EU by Australia and the USA to the World Trade Organization (WTO). ${ }^{7}$

3 A provision in which an old rule continues to apply to some existing situations while a new rule will apply to all future cases.

4 See ec.europa.eu/agriculture/wine/third-countries/index_en.htm.

5 Council Regulation (EEC) No. 2081/92 of 14 July 1992 (eur-lex.europa.eu/legal-content/EN/ TXT/PDF/?uri=CELEX:31992R2081\&from=EN).

6 Council Regulation (EC) No. 510/2006 of 20 March 2006 also incorporated some other changes, including dropping the requirement for a published list of generic names (see Profeta et al. 2009: 633) (europa.eu/legislation_summaries/internal_market/businesses/intellectual_property/ 166044_en.htm).

7 WTO dispute DS290, EC - Trademarks and Geographical Indications (www.wto.org/english/ tratop_e/dispu_e/cases_e/ds290_e.htm). 
It was revised again in 2012. ${ }^{8}$ The system identifies three separate types of designation: protected designation of origin (PDO), protected geographical indication (PGI), and traditional specialty guaranteed (TSG). TSGs are little used at present and are not further discussed in this chapter. They provide few difficulties for competition policy because production need not take place in the specified geographical area. Recently, the EU has begun to consider extending GIs to non-agricultural products. ${ }^{9}$ This issue too is beyond the scope of this chapter, which looks only at GIs for agricultural products and foodstuffs.

While the privileges provided by PDOs and PGIs are identical-in neither case may a competitor from outside the designated region use the name, even with clear qualifiers - the requirements are very different. PDOs have strict production controls and the key ingredients must, in theory, be produced within the designated area. ${ }^{10}$ In contrast, PGIs are far more flexible in terms of the sourcing of inputs, and seem to be able to have limited association with the designated region. Indeed, issues have been raised that this flexibility in the origin of materials for PGI products can make such labelling misleading for consumers (London Economics 2008: 86-91).

There have been a number of initiatives to promote the use of GIs within the EU, ${ }^{11}$ and there have been impressive increases in the number of registered PDOs and PGIs; from 1993 to the end of 2012, PDOs

8 Regulation (EU) No. 1151/2012 of 21 November 2012 (eur-lex.europa.eu/legal-content/ EN/TXT/PDF/?uri=CELEX:32012R1151\&from=en) followed a rather poor-quality evaluation of the GI program, largely because of the absence of relevant data. The EU's Impact Assessment Board considered that the added value of the GI schemes had not been demonstrated (European Commission 2010a: 6).

9 The two EU studies are at trade.ec.europa.eu/doclib/docs/2011/may/tradoc_147926.pdf and ec.europa.eu/internal_market/indprop/docs/geo-indications/130322_geo-indications-non-agristudy_en.pdf. France has recently promulgated regulations for non-agricultural GIs (www.inta.org/ INTABulletin/Pages/France_7015.aspx).

10 In practice, raw materials can come from a far wider area for PDOs registered before May 2004 (Calboli 2014).

11 A special fast-track registration system was initially used to encourage GI applications, but in 2003 this was abandoned in favour of financial incentives (Evans \& Blakeney 2006: 584). Some member states provide direct financial and administrative assistance for producer groups to establish GIs (London Economics 2008: 118-19). 
increased by 19 per cent and PGIs by 40 per cent (Figure 1$).{ }^{12}$ The initial set of GIs, with 369 PDOs and 281 PGIs, were largely names transferred from national registers to the $\mathrm{EU}$ register.

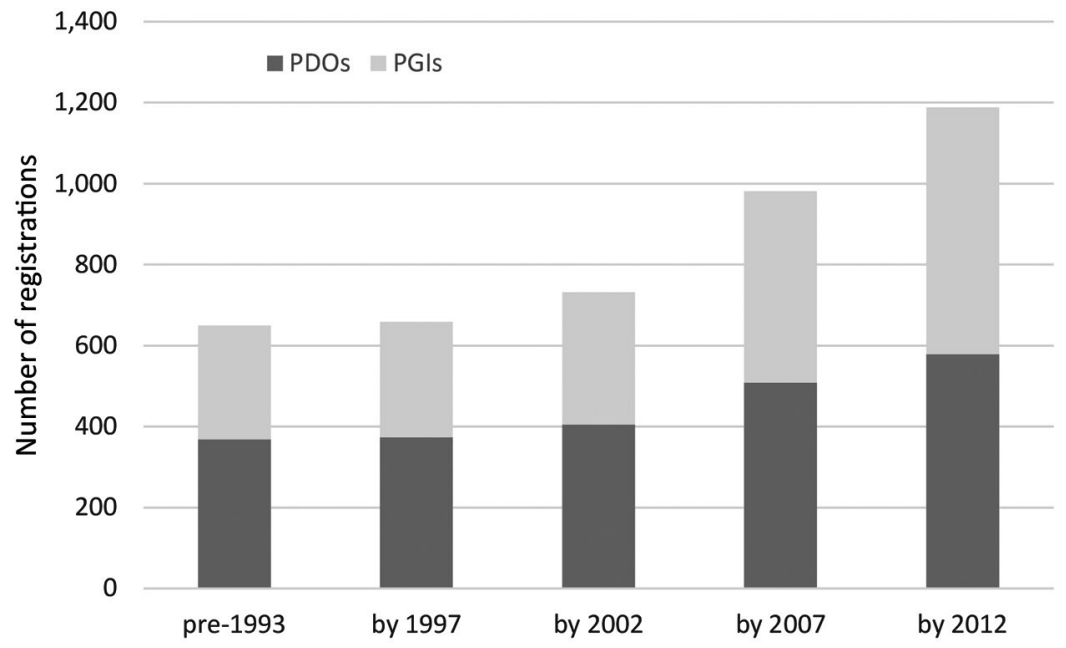

Figure 1. Growth in EU-registered Gls

Source: Author analysis from data from the DOOR database.

Of the 1,188 registrations filed by end 2012, 75 per cent (887) were owned by France, Greece, Italy, Portugal and Spain. These five countries had 87 per cent of initial PDO registrations and still have 85 per cent of such registrations. They had 75 per cent of initial PGI registrations, but this share had fallen to 64 per cent by the end of 2012 .

London Economics (2008) has noted that the countries dominating the GI system have large agricultural sectors. Other relevant variables to benchmark the relative use of GIs are population and size of the total economy, variables that reflect aspects of consumer demand. These benchmarks put the dominant use of GIs by France, Italy and Spain into perspective. The three right-hand columns of Table 1 provide summary indicators of whether a country has more or fewer GIs than would be expected simply on the basis of population, gross domestic product (GDP) or agricultural value added shares.

12 Data are from the DOOR database (ec.europa.eu/agriculture/quality/door/list.html). Data were downloaded on 6 July 2015 and are analysed by application year (the point at which the decision to seek registration of a GI is first recorded). All applications from EU member states registered by 6 July 2015 are counted. Unless otherwise specified, data in all tables and figures are from this source. 
AUSTRALIA, THE EUROPEAN UNION AND THE NEW TRADE AGENDA

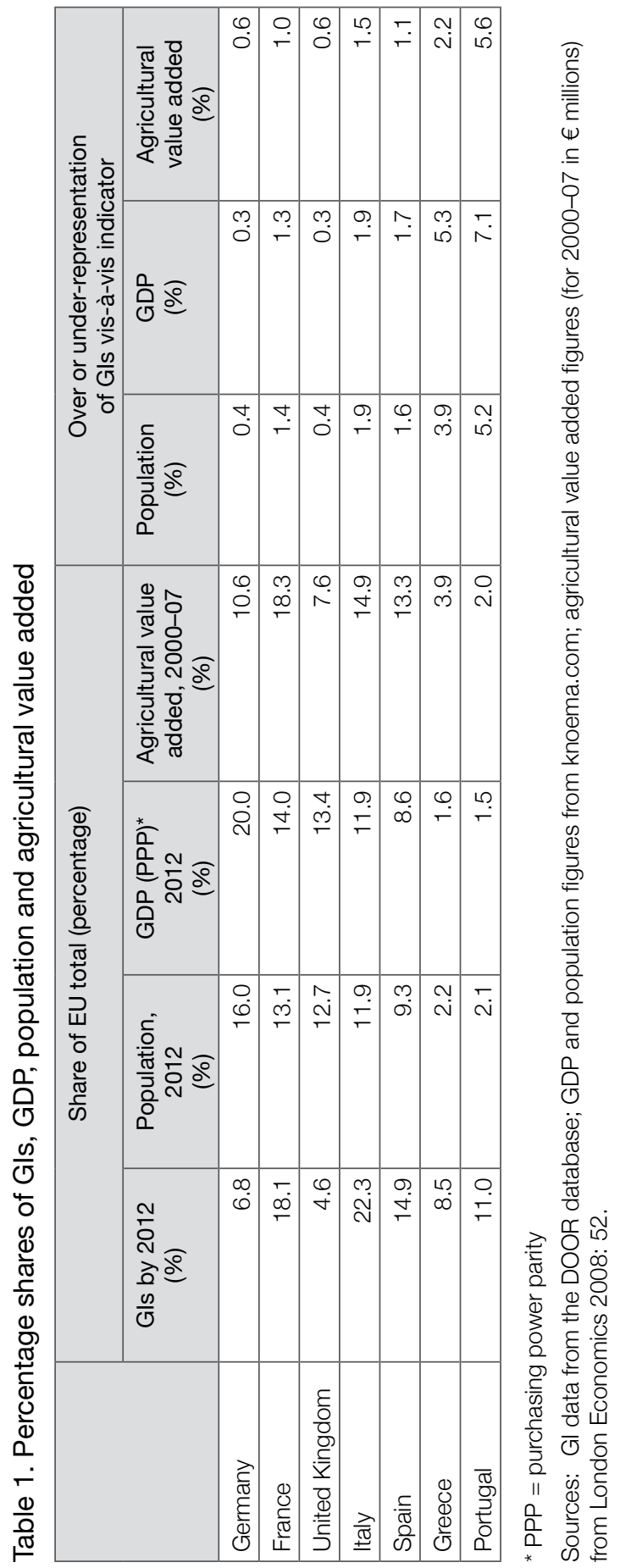


On an agricultural value added basis, the proportion of GIs owned by France is what one would expect were GI ownership based solely on agricultural value added. Similarly, Spanish GI ownership is only 10 per cent higher than expected. But Italian GI ownership is 50 per cent greater than would be expected on the basis of the size of its agricultural sector, and 90 per cent higher than expected based on population or GDP share (Table 1).

The two countries that are truly over-represented in terms of GI ownership are Greece and Portugal. The proportion of GIs owned by Greece is more than twice what one would expect based on the size of the agricultural sector, more than five times as large with respect to GDP share and nearly four times as large based on population. Portugal's over-representation in terms of GI share is even more striking-between five and seven times larger than expected. In contrast, Germany and the United Kingdom are substantially under-represented in terms of the share of registered names.

What these data do not tell us is how important GI products are and to whom. There are few data on the number of producers involved in any registered GI. ${ }^{13}$ There are few data on the value of output, and often output values are given without any context. Thus, we may be told how many millions of PDO output is sold, but not the proportion of total agricultural output or agricultural and food-processing output. Indeed, such data are available only for France and Spain. But even here we do not get a good denominator for the French data-while GI products are 6.3 per cent of total French agricultural output, many GI products are processed and we do not know what percentage they are of total French output from agriculture and food processing. For Spain, this figure is just 1 per cent. ${ }^{14}$

While much of the discussion on GIs implies that most GI producers are small operators, it is clear that in some product lines very large producers play an important role. Rangnekar, for example, points out that in a case study of Tuscan extra virgin olive oil less than 2 per cent of certified production was by small producers (Rangnekar 2004: 5).

13 London Economics (2008: 107) provides data for total producers involved in all registered names for only six countries, and some of these data are partial. The proportion of all producers/ processors involved in GI products is available only for France and Italy.

14 London Economics 2008: 107-9. Although more data are available in a separate European Commission commissioned report, this study too avoids giving relevant comparators for most statistics (AND-International 2012). The one useful comparison figure is that PDO/PGI agricultural products and foodstuffs represented about 2 per cent of the total value of extra-EU food exports in 2010. 


\section{Rationales for the Gl intervention}

The EU regulations, introduced in 1992 and amended in 2006 and 2012, show clearly that GIs are an important element of EU agricultural policy, with the additional stated aim of reducing consumer confusion. This second aim, the basis for using an IP mechanism, requires interrogation. It is based on economic theories about information asymmetries, developed in respect of consumer durables. ${ }^{15}$ But most food and drink purchases are regularly repeated events, and so differ substantially from durable goods. The frequency of food purchases means that consumers quickly overcome any initial information asymmetry. This is rarely noted in the GI literature. ${ }^{16}$

This leaves the sole consumer information asymmetry argument for GIs as being that high-end agricultural products are credence goodsthat despite purchase and use, the consumer may still be misled as to quality attributes. This argument applies to situations where the quality of a GI product does not noticeably vary between the GI region and non-GI regions. The core of the EU argument on GIs is therefore the presumption that consumers are confused, even if they are not-even if the taste experience is identical, consumers will be confused if their cheese is labelled 'brie-style cheese, product of Australia'.

Given the failure of consumer confusion justifications to stand up to scrutiny, are there producer arguments for the GI intervention? GIs are similar to trademarks, though their associated privileges are much stronger and they cannot be individually owned or traded. The producer argument for trademarks is that producers are protected from counterfeiter trading on their reputation. But the strong-form GI privilege prevents clear labelling that advises consumers clearly of the origin of the goods. Further, in the EU the registered GI name is protected well beyond the class of goods to which a similar trademark would apply. This might be justifiable if it increased net welfare; that is, if the gains to these producers and previously 'confused' consumers were greater than the losses to other producers and consumers who are not shopping for high-end food products. This is an empirical matter.

15 For an excellent and brief summary of this literature, see OECD (2000, Annex 1).

16 See, for example, Bramley, Biénabe \& Kirsten (2009). An important exception is Teuber (2011), who also provides a sound analysis of the economic literature to date. 
There is surprisingly little empirical literature on GIs. The literature on willingness to pay shows variable outcomes except for one issue: only a very small share of consumers are willing to pay a price premium for a higher-quality product (Bramley, Biénabe $\&$ Kirsten 2009). This finding is reflected in the outcome of the 2008 EU GI evaluation-retailers report that GI products have little impact on their profitability as they constitute a very low proportion of goods sold (London Economics 2008: 147-50). The even sparser empirical literature on the economic impact of GIs shows that the impact of GIs on rural development is variable and contingent, as is the overall economic impact (Callois 2004; Zago \& Pick 2004; Bramley, Biénabe \& Kirsten 2009; Grote 2009; Teuber 2011).

The above analysis suggests that agricultural goals remain the sole justification for GIs. But the policy is implemented in the form of an IP right, and in the best traditions of IP policy, the implementing processes are all formalities and procedural matters. There are no economic criteria brought to bear on key issues such as how regions are defined, what proportion of a production chain is designated, or how the proposed GI will impact on competitors. European GI policy trumps competition policy, without any questions asked.

Case law on GIs shows that there are few, if any, competition controls on the registration of a GI name. The Parma ham case raises doubts as to the processes in place for defining the length of the production chain covered by a registered GI (Evans \& Blakeney 2006). The Melton Mowbray pork pie case raises doubts as to the processes in place for defining designated regions (Gangjee 2006). And the feta case shows that GIs are allowed to override existing trademark rights without any compensation mechanisms (Gangjee 2007). ${ }^{17}$ As GIs are defined as 'industrial property' they are excluded from the application of the EU treaty articles that prohibit quantitative restrictions on exports. These articles are fundamental to the creation of a single competitive European market. Either GIs should be recognised as agricultural policy instruments and removed from this exemption, or procedures should be introduced to minimise anticompetitive elements in GI registration processes.

The EU's approach contrasts sharply with Australia's processes for certification marks. The Australian Competition and Consumer Commission (ACCC) is required to examine any proposed certification

17 These cases are discussed in Moir (2015b: 14-18). 
mark 'to ensure [the proposed rules] are not to the detriment of the public, or likely to raise any concerns relating to competition, unconscionable conduct, unfair practices, product safety and/or product information'. ${ }^{18}$ Only after an application has passed ACCC scrutiny can it be registered as an Australian certification mark. To date, only foreign organisations have used Australia's certified mark system to register geographical names, though there are two pending domestic applications, one for the Mornington Peninsula and one for Hinchinbrook shire. ${ }^{19}$ Clearly, overseas GI producers are using the system. Equally clearly, there is as yet little demand from Australian producers.

\section{EU Gl goals and recent trade treaty outcomes}

The analysis of the EU's GI demands is based on a close reading of the EU's new generation economic agreements with Canada, Central America, Columbia/Peru, Korea and Singapore. The EU's principal goals in GI negotiations with other countries are sui generis register-based systems, strong-form protection for all GIs, and administrative enforcement.

\section{Register-based systems}

Two of the EU's post-Global Europe treaties appear to require sui generis ${ }^{20}$ register-based systems. These are with Central America and Singapore. ${ }^{21}$ Three have clauses specifying systems that sound like sui generis registerbased systems. But the legal language used in treaties can mislead.

18 www.accc.gov.au/business/applying-for-exemptions/certification-trade-marks.

19 As at the end of 2015 there were 474 registered certified marks in Australia, of which 116 were exclusively for agricultural products and a further 47 for both agricultural and non-agricultural classes of goods. An additional 41 certified marks for agricultural products were pending. Excluding the 21 registered marks for wines, only 19 marks were geographic marks registered (12 from Italy, two each from India, Jamaica and the USA, and one from the United Kingdom).

20 That is, a special form of protection regime outside the existing frameworks, or a regime especially tailored to meet a certain need.

21 Singapore has passed legislation that will come into force when the Treaty with the EU commences (www.wongpartnership.com/index.php/files/download/1259). At present the Intellectual Property Office of Singapore (IPOS) advises that GIs can either be protected as GIs or under the Trade Marks Act (www.ipos.gov.sg/AboutIP/TypesofIPWhatisIntellectualProperty/ Whatisageographicalindication.aspx). This parallels the EU, with regulations governing both GIs and Community Trade Marks (CTMs). For a useful discussion of the relative merits of EU GIs or EU CTMs see Evans 2010. 
From the treaty text it sounds like Korea agreed to such a system, ${ }^{22}$ but the Korean Intellectual Property Office website clearly states that in Korea GIs are registered under the trademark system as collective marks. ${ }^{23}$ Canada also retains its trademark-based system for GIs. The EU-Andean treaty does not directly touch on this issue; it is far shorter and less prescriptive than the other four treaties.

Associated with a register-based system is the requirement for transparent processes including opposition and appeal procedures. Other associated elements in the treaties are all very process-oriented, a characteristic of most IP regulations. As such, they are ideally suited to delivery of GIs through a trademark system, itself usually register based. The EU's Korean and Singaporean agreements have the largest number of EU-specified elements in the agreed GI procedures.

All five treaties include procedures for adding new GI names, and all list names that are to be recognised as GIs in the other jurisdiction. ${ }^{24}$ These lists are subject to examination and opposition procedures in each country and there is a process for ensuring that names that have passed these processes are protected as GIs. ${ }^{25}$ In all cases, the lists of names are very much longer for the EU than for the other party, and the EU lists have expanded. In the agreement with Colombia/Peru the EU listed 34 foods; in the EU-Korea agreement they listed 60 foods; in the EU-Singapore agreement they listed 82 foods; and in the 2014 Comprehensive Economic and Trade Agreement (CETA) the EU listed 173 foods. In contrast, Colombia/Peru listed only three foods and two non-foods. As yet, there is no information on GIs that Singapore and Canada might list. Korea appears to be one country that might use GIs as much as the EU-they listed 60 foods.

The 2014 implementation report on the EU-Korea agreement notes that the GI Working Group met for the first time in October 2012. The Working Group had discussed but not yet adopted rules of

22 Article 10.18.6, ec.europa.eu/trade/policy/countries-and-regions/countries/south-korea/.

23 'In the Republic of Korea, geographical indications have been protected as a collective mark under the Trademark Act (Act No. 7290) since July 1, 2005' (www.kipo.go.kr/kpo/user.tdf?a=user. english.html.HtmlApp\&c=930002\&catmenu=ek04_01_01, dated 20 February 2013 and accessed 22 February 2015).

24 Though the documents available as at December 2015 do not yet show GI name lists for Singapore or Canada.

25 In general, the treaties specify that opposition and examination procedures for listed GIs have already been completed or will be completed by the time the treaties come into force. As at the end of 2015, no GIs listed in Global Europe treaties for partner countries appear on the DOOR register. 
procedure. Clearly, the priority for the Working Group was the new GIs that the EU had already proposed. The implementation report (European Commission 2014: 8) advises that:

The EU emphasised the interest that EU Member States attach to GIs and the importance of increasing the list by as many GIs as necessary. Korea also announced the intention of proposing Korean GIs to the said Annex. ${ }^{26}$

\section{Strong-form protection}

A second EU priority is to gain strong-form protection for all GIs. Strongform privileges lead to clawback of names that are generic in some parts of the world. The EU has achieved strong-form protection for many non-wine foodstuffs in the agreements with Korea, Central America, Singapore and Canada. In the cases of Colombia and Peru, the agreement allows weakform GIs for wines and spirits, but leaves the door open for the adoption of strong-form protection, including for foodstuffs. It also extends GI protection beyond agricultural products. The EU-Andean agreement also covers misleading packaging, advertising or other practices. The use of flags and other images to denote a specific country or region is considered by the EU to undermine GI privileges.

Canada has agreed to allow coexistence of EU GIs with pre-existing Canadian trademarks. The EU claims this as a strong precedential victory, as it "establishes for the first time in a common law" country like Canada a deviation from the principle "first in time first in right" (European Union 2014: 14-15). Canada has, however, grandfathered certain GI names, providing for perpetual rights for existing users of the names feta, asiago, gorgonzola, fontina and munster. New producers will also be able to use these names, but with qualifiers. ${ }^{27}$ Canada has also specified that any new GI names cannot be the same as existing trademarks, so the agreed coexistence is very limited in scope.

26 See trade.ec.europa.eu/doclib/docs/2014/march/tradoc_152239.PDF. As at January 2016, this was the latest available information about the implementation of agreed GI policy in the EU-Korea agreement.

27 The agreement also contains similar protections for the names of three meat products (Article 7.6). 
These privileges need to be assessed side-by-side with the agreed safeguards. Like TRIPS, all five new generation EU treaties include important safeguards. ${ }^{28}$ All provide that a GI will not be registered if it will cause confusion with an existing reputed or well-known mark, at least partially protecting trademark owners from appropriation. Existing trademarks may continue under all five treaties.

Some of the treaties allow continued trading using a geographical name if that has been past practice (Singapore, Canada). Some allow refusal of a GI if the name is customary. ${ }^{29}$ Generally there is some form of prohibition on the use of plant variety or animal breed names-sometimes limited to where this will cause confusion (Korea), or to new GIs (Canada). ${ }^{30}$ All allow a person to use their own name to trade as long as this will not cause consumer confusion.

\section{Administrative enforcement}

The third EU GI priority is administrative enforcement-this shifts enforcement costs from individual rights-holders to the overseas taxpayer. This appears to have been achieved in both the EU-Korea and EUCanada agreements, but the EU has claimed neither as a precedent-setting win. ${ }^{31}$ But as the benefit of a GI goes to the producer, the rationale for overseas taxpayers to pay enforcement costs is unclear. With a trademark the benefit accrues to the producer and enforcement is a responsibility of the producer. Why should enforcement costs for GIs be shifted to either domestic or overseas taxpayers?

The analysis paper accompanying the explanatory memorandum provided to the European Parliament for the 2012 revision of the EU's GI regulation considers a number of options for reform. The most important optionone that would ease trade negotiations-is that of using Community

28 The EU treaties with the Andean and Central American countries are more general than the other three treaties, with far fewer operational details specified, and fewer safeguards spelled out.

29 The EU-Central America treaty even allows continued use of customary names for wines and spirits.

30 Oddly, the EU-Singapore agreement states that a conflict with the name of a plant variety or animal breed will not prevent a GI being registered (Article 11.22.8). This may well be a typographical error as the EU regulations on GIs prohibit a GI 'where it conflicts with a name of a plant variety or an animal breed and is likely to mislead the consumer as to the true origin of the product' (Article 6.2, EU Regulation No. 1151/2012 and Article 3.2 in the 1992 and 2006 regulations).

31 The CETA wording is ambiguous and may simply allow GI owners to use administrative processes to resolve disputes rather than requiring official authorities to enforce GI names (Article 7.4). 
Trade Marks (CTMs). ${ }^{32}$ Important reasons given for dismissing this option include complexity (i.e. trademark registration would be needed in each country), cost (of trademark registration and enforcing such trademarks) and the lower degree of privilege. In respect of the latter, the paper notes that CTMs would allow competitors to use the registered name 'provided he [sic] uses them in accordance with honest practices in industrial or commercial matters' (European Commission 2010a: 33). Essentially, the lower degree of privilege would mean that potentially infringing practices would not actually infringe if consumers were not misled and the indication was used honestly. New World countries find this position hard to understand and hard to accept.

\section{Evaluating the EU's GI demands}

It was the EU who alone pushed for the inclusion of GIs in TRIPS. The EU remains committed to the extension of strong-form GI protection globally. In the Doha Round negotiations, the EU linked the agenda of yet stronger GI rights to developing country demands for fair sharing of genetic resources and protection of traditional knowledge, potentially extending GIs to non-agricultural products. This has created two blocks, divided both on the GI issue and on recognition of genetic resources. As at 2009, 111 countries had sui generis GI systems and 56 had trademark systems (Giovannucci et al. 2009: 14).

There are reports that GIs are a deal-breaker for the EU in relation to preferential economic agreements. Given that the multilateral trade negotiations are stalled, it is as yet impossible to say whether this is a deal-breaker globally. Certainly the post-2006 EU trade agreements all include GIs, though in some cases GI privileges do not move much beyond TRIPS.

To date, Australia has refused absolutely to consider any extension of strong-form GIs beyond wines and spirits. Unless Australia is able to bring together interested parties and be more open to other options on the GI issue, there is little point in commencing trade negotiations with the EU.

32 The system for EU-wide trademarks only came into operation in 1988, just four years before the first EU GI regulation was issued. In complete contrast to the GI system, a nation can object to a CTM being registered if it is a word that is generic in that country, and this prevents the CTM being registered. 
The door to a more accommodating position has been opened by the recent report for the Rural Industries Research and Development Corporation (van Caenegem, Drahos \& Cleary 2015). Further, the actual GI changes to Canadian policy consequent on CETA appear modest. It would seem possible, on this basis, that Australia might begin a domestic consultation and reform process to identify a GI strategy that both suits Australian interests and meets minimum EU demands. Such work could usefully incorporate an evaluation of the value of certification marks for GI policy purposes and explore why there is so little domestic demand for GIs for foodstuffs. Any GI strategy should learn from and avoid the worst pitfalls of EU GI policy. There should be clear economic criteria used in defining GIs, and a process, such as that in place for certification marks, to ensure anti-competitive effects are minimised. Consideration should be given to excluding GIs from the IP exception to competition laws.

Another missing element in EU GI policy is compensation for losers. Indeed, EU GI policy eliminates the absolute safeguards that are part of its CTM policy. ${ }^{33}$ Should a new GI policy lead to trademark expropriation, there needs to be a clear procedure for providing sufficient compensation to create new marketing images. Ideally, this should be provided by the GI winners. For New World wine and spirit producers, such compensation took the form of increased access to EU markets.

In designing a GI system, Australia might be mindful:

- of the value of retaining weak-form GIs - these provide for consumer recognition of known products while allowing reasonable competition among producers. Canada has been able to protect important generic names such as feta in its negotiations with the EU, and Australia might develop a shortlist of generic names that are important in our markets;

- of the need to protect trademark rights or provide compensation where these rights have to be surrendered. The compensation should be from the winning party to the party that will have to begin anew on its marketing and market positioning;

- of the effectiveness of certified trademarks in providing appropriate protection for regional producers; and

33 Under the CTM policy any member state can object to a proposed registration, including on grounds that the name has become common or generic in their state, and the CTM registration will then fail. 
- GIs being a government-enforced privilege that allows the users to extract a higher price from their consumers. These privileges come at a cost to consumers and to some producers. It is not reasonable, therefore, for enforcement action (and costs) to be shifted from the privilege-holders to taxpayers.

\section{References}

AND-International (2012), Value of production of agricultural products and foodstuffs, wines, aromatised wines and spirits protected by a geographical indication (GI), Commissioned by the European Commission (tender no. AGRI-2011-EVAL-04). Available at ec.europa. eu/agriculture/external-studies/2012/value-gi/final-report_en.pdf.

Bramley, Cerkia, Estelle Biénabe, \& Johann Kirsten (2009), 'The economics of geographical indications: Towards a conceptual framework for geographical indication research in developing countries', in WIPO (eds), The Economics of Intellectual Property: Suggestions for Further Research in Developing Countries and Economies in Transition (World Intellectual Property Organization: Geneva), 109-49.

Calboli, Irene (2014), 'In territorio veritas: Bringing geographical coherence into the definition of geographical indications of origin under TRIPs', The WIPO Journal 6(1): 57-67.

Callois, Jean-Marc (2004), Can Quality Labels Trigger Rural Development? A Microeconomic Model with Co-operation for the Production of a Differentiated Agricultural Good, Working Paper No. 2004/6 (Centre d'Economie et Sociologie appliquées à l'Agriculture et aux Espaces Ruraux: Dijon).

European Commission (2010a), Impact Assessment on Geographical Indications: Accompanying Document to the Proposal for a Regulation of the European Parliament and of the Council on Agricultural Product Quality Schemes, Commission Staff Working Paper (European Commission: Brussels). Available at ec.europa.eu/agriculture/sites/ agriculture/files/quality/policy/quality-package-2010/ia-gi_en.pdf.

European Commission (2010b), Summary Impact Assessment on Geographical Indications, Commission Staff Working Paper, SEC(2010) 1525 Final (European Commission: Brussels). Available at ec.europa.eu/agriculture/sites/agriculture/files/quality/policy/qualitypackage-2010/ia-gi-summary_en.pdf. 
European Commission (2014), Annual Report on the Implementation of the EU-Korea Free Trade Agreement, COM(2014) 109 Final (European Commission: Brussels). Available at trade.ec.europa.eu/doclib/docs/ 2014/march/tradoc_152239.PDF.

European Union (2014), 'CETA-Summary of the final negotiating results'. Available at trade.ec.europa.eu/doclib/docs/2014/ december/tradoc_152982.pdf, last accessed 5 August 2015.

Evans, G.E. \& M. Blakeney (2006), 'The protection of geographical indications after Doha: Quo vadis?', Journal of International Economic Law 9(3): 575-614. doi.org/10.1093/jiel/jgl016.

Gangjee, Dev (2006), 'Melton Mowbray and the GI pie in the sky: Exploring cartographies of protection', Intellectual Property Quarterly 3: 291-309.

Gangjee, Dev (2007), 'Say cheese! A sharper image of generic use through the lens of Feta', European Intellectual Property Review 29(5): 172-79.

Geuze, Matthijs (2009), 'The provisions on geographical indications in the TRIPS Agreement', Estey Centre Journal of International Law and Trade Policy 10(1): 50-64.

Giovannucci, Daniele, Tim Josling, William Kerr, Bernard O'Connor, and May T. Yeung (2009), Guide to Geographical Indications: Linking Products and Their Origins (International Trade Centre: Geneva). Available at www.intracen.org/itc/market-info-tools/geographicalindications/.

Grote, Ulrike (2009), 'Environmental labeling, protected geographical indications, and the interests of developing countries', Estey Centre Journal of International Law and Trade Policy 10(1): 94-110.

London Economics (2008), Evaluation of the CAP policy on protected designations of origin (PDO) and protected geographical indications (PGI): Final report (London Economics: London). Available at ec.europa.eu/agriculture/eval/reports/pdopgi/report_en.pdf.

Moir, Hazel V. J. (2015a), European Trade Treaties: Key Intellectual Property Demands, ANU Centre for European Studies Briefing Paper Series, 6(4) (Canberra: ANU Centre for European Studies). Available at politicsir.cass.anu.edu.au/research/publications/europeantrade-treaties-key-intellectual-property-demands-1. 
Moir, Hazel V. J. (2015b), 'Geographic Indications: heritage or terroir?', Paper presented at 10th Annual Conference of the EPIP Association (European Policy for Intellectual Property), Parallel Session 4BGeographical Indications and Regions, 2-3 September 2015, University of Glasgow. doi.org/10.2139/ssrn.2656136.

OECD (2000), Appellations of Origin and Geographical Indications in OECD Member Countries: Economic and Legal Implications, COM/AGR/APM/TD/WP(2000)15/FINAL (OECD: Paris). Available at www.oecd.org/officialdocuments/publicdisplaydocument $\mathrm{pdf} /$ ?cote $=\mathrm{COM} / \mathrm{AGR} / \mathrm{APM} / \mathrm{TD} / \mathrm{WP} \% 282000 \% 2915 / \mathrm{FINAL} \&$ doclanguage $=$ En .

Profeta, Adriano, Richard Balling, Volker Schoene, and Alexander Wirsig (2009), 'The protection of origins for agricultural products and foods in Europe: Status quo, problems and policy recommendations for the Green Book', The Journal of World Intellectual Property 12(6): 622-48. doi.org/10.1111/j.1747-1796.2009.00380.x.

Rangnekar, Dwijen (2004), The Socio-Economics of Geographical Indications: A Review of Empirical Evidence from Europe, UNCTADICTSD Issue Paper No. 8 (International Centre for Trade and Sustainable Development and United Nations Conference on Trade and Development: Geneva). Available at www.ictsd.org/sites/default/ files/research/2008/07/a.pdf.

Teuber, Ramona (2011), 'Protecting Geographical Indications: Lessons learned from the Economic Literature', paper presented at European Association of Agricultural Economists, 2011 International Congress, 30 August-2 September 2011, Zurich, Switzerland.

van Caenegem, William, Peter Drahos, and Jen Cleary (2015), Provenance of Australian Food Products: Is There a Place for Geographical Indications?, RIRDC No. 15/060 (Rural Industries Research and Development Corporation: Canberra). Available at rirdc.infoservices. com.au/downloads/15-060.

Zago, Angelo M. and Daniel H. Pick (2004), 'Labeling policies in food markets: Private incentives, public intervention, and welfare effects', Journal of Agricultural and Resource Economics 29(1): 150-65. 
This text is taken from Australia, the European Union and the New Trade Agenda, edited by Annmarie Elijah, Don Kenyon, Karen Hussey and Pierre van der Eng, published 2017 by ANU Press, The Australian National University, Canberra, Australia. 